\title{
Early sofosbuvir-ledipasvir treatment for acute HCV infection induced severe immune thrombocytopenia - a case report
}

\author{
Vincent Alcazer $^{1,2^{*}}$ (D) Patrick Miailhes ${ }^{3}$, Christophe Ramière $2,4,5$, Caroline Charre ${ }^{2,4,5}$ and Laurent Cotte ${ }^{3}$
}

\begin{abstract}
Background: Hepatitis C virus (HCV) infection is a recognised cause of secondary immune thrombocytopenia (ITP). While its incidence has been largely described during chronic HCV infection, only one case of ITP secondary to acute HCV infection has been reported at this time.

Case presentation: We report herein the case of severe ITP secondary to an acute HCV genotype 1a reinfection in a human immunodeficiency virus (HIV)-negative man having sex with men who had been cured several years before of a previous acute genotype $4 \mathrm{~d} \mathrm{HCV}$ infection. After an unsuccessful standard therapy with two courses of intravenous immunoglobulin (at $1 \mathrm{~g} / \mathrm{kg}$ daily for 2 days) associated with methylprednisolone $1 \mathrm{mg} / \mathrm{kg}$ daily, antiviral treatment with sofosbuvir-ledipasvir rapidly achieved virological response and normalised the platelet count.

Conclusions: As a direct effect of HCV on megakaryocytes could be the predominant cause of ITP during acute infection, early antiviral treatment may be beneficial in this case.
\end{abstract}

Keywords: Hepatitis C virus, Sofosbuvir-ledipasvir, Acute immune thrombocytopenia

\section{Background}

Immune thrombocytopenia (ITP) is an acquired thrombocytopenia caused by immune platelet destruction. Most adults $(80 \%)$ present a primary ITP in which different mechanisms contribute to a reduced platelet lifespan, involving mostly antibody- or T cell-mediated platelet destruction and impaired megakaryocytopoiesis [1]. Secondary ITP pathogenesis is slightly different and relates to underlying disorders among which infections, auto-immune diseases, and lymphoproliferative disorders are the leading causes [2].

Hepatitis C virus (HCV) infection is a recognised cause of secondary ITP [3]. Its occurrence has been well described in the case of chronic infection where the diagnosis can be difficult as different factors can contribute to thrombocytopenia including cross-reactive antibodies

\footnotetext{
*Correspondence: vincent.alcazer@chu-lyon.fr

'Département d'hématologie clinique, Hospices Civils de Lyon, Centre Hospitalier Lyon Sud, 69495 Pierre-Bénite, France

${ }^{2}$ Inserm U1052, Centre de Recherche en Cancérologie de Lyon, 69008 Lyon, France

Full list of author information is available at the end of the article
}

directed against platelet antigens, bone-marrow viral infection of progenitor cells, decreased production of thrombopoietin and splenic sequestration secondary to portal hypertension [2]. However, few cases of ITP secondary to acute hepatitis $\mathrm{C}$ virus $(\mathrm{HCV})$ infection have been reported to date.

Herein we report the case of a patient with severe secondary ITP during an acute HCV genotype 1a reinfection. Early treatment with sofosbuvir-ledipasvir allowed the prompt recovery of thrombocytopenia.

\section{Case presentation}

In July 2017, a 54-year-old male was hospitalised for the recent appearance of multiple purpuric spots on the legs associated with gum bleeding. The patient was an HIVnegative man having sex with men, receiving HIV preexposure prophylaxis with tenofovir/emtricitabine for over a year. His medical history was significant for a primary syphilis in 2014 and multiple episodes of urethritis in the recent years. He reported frequent unprotected anal sex, with occasional bleeding, insertive and receiving fisting without gloves, and the use of nasal mephedrone during sexual encounters. He was previously diagnosed with an

(c) The Author(s). 2018 Open Access This article is distributed under the terms of the Creative Commons Attribution 4.0 International License (http://creativecommons.org/licenses/by/4.0/), which permits unrestricted use, distribution, and reproduction in any medium, provided you give appropriate credit to the original author(s) and the source, provide a link to the Creative Commons license, and indicate if changes were made. The Creative Commons Public Domain Dedication waiver (http://creativecommons.org/publicdomain/zero/1.0/) applies to the data made available in this article, unless otherwise stated. 
acute genotype $4 \mathrm{HCV}$ infection in 2011 (Versant HCV genotype 2.0 assay (LiPA), Siemens Healthineers, Erlangen, Germany), cured following a 6-month course of pegylated interferon (IFN) and ribavirin. Acute genotype 1a HCV reinfection was diagnosed on 2017, June 26th (NS5A Sanger sequencing), while HCV-RNA was still negative on 2017, April 4th (Abbott RealTime HCV, Abbott, Molecular, Des Plaines, USA). The patient was asymptomatic at that time, platelet count was normal and HCV-RNA surveillance was scheduled, following the recommendations from the European AIDS clinical society [4].

Initial physical examination found no other symptoms apart from a petechial purpura of the lower extremities and oral haemorrhagic blister. Blood pressure was 130/ $97 \mathrm{mmHg}$, heart rate $60 \mathrm{bpm}$ with no fever, lymphadenopathy, or splenomegaly. There was no evidence of severe haemorrhage. Laboratory data at the admission are resumed in Table 1. Complete blood count found a severe thrombocytopenia $(5 \mathrm{G} / \mathrm{L})$ without any other cytopenia. Thrombocytopenia was confirmed on the peripheral blood smear which exhibited no morphological abnormalities and the absence of schistocytes. No other associated haemostasis abnormality was present (normal fibrinogen and factor V). Serum protein electrophoresis found no clonal gammopathy. Thyroid-stimulating hormone was normal. HIV serology was repeatedly negative and Hepatits B surface antibodies were detectable following a previous vaccination. At that time, mild elevation in aspartate transaminase (AST, 6 times the upper limit of normal (ULN)) and alanine transaminase (ALT, $7 \times$ ULN) was found associated with a detectable HCV viral load of $4.9 \log \mathrm{IU} / \mathrm{mL}$ (Fig. 1). There was no evidence of other replicating viruses including cytomegalovirus, parvovirus B19, human herpes virus type 6 and type 8 (except a slight Epstein-Barr virus replication which was considered insignificant (348 UI/mL). Cryoglobulin investigation was negative. No circulating anti-platelet IgG antibodies were detected. A bone marrow aspiration was performed; normal cellularity with an increased number of megakaryocytes and normal erythropoiesis and myelopoiesis was found, thus confirming the diagnosis of ITP secondary to acute $\mathrm{HCV}$ infection.

An initial administration of intravenous immunoglobulin (IVIG; at the dose of $1 \mathrm{~g} / \mathrm{kg}$ on day 1 and day 3 ) had clinical benefit (regression of gum bleeding and purpura), but did not have any effect on the platelet count which remained below 10G/L. A second administration of IVIG $(1 \mathrm{~g} / \mathrm{kg}$ daily for 2 days) combined with methylprednisolone $(1 \mathrm{mg} / \mathrm{kg}$ daily) improved platelet count which reached 40G/L but a normal value was not attained (Fig. 1). At which point it was decided after collegial discussion to start treating the infectious trigger. Pegylated IFN and ribavirin combination was contra-indicated because of severe thrombocytopenia,
Table 1 Laboratory data at the admission

\begin{tabular}{|c|c|c|}
\hline Parameter & Baseline value & $\begin{array}{l}\text { Normal value } \\
\text { (range) }\end{array}$ \\
\hline \multicolumn{3}{|l|}{ Complete blood count } \\
\hline Leucocytes & $5.69 \mathrm{G} / \mathrm{L}$ & $4.00-10.00$ \\
\hline Haemoglobin & $149 \mathrm{~g} / \mathrm{L}$ & $130-170$ \\
\hline MCV & $95.0 \mathrm{fL}$ & $80-100$ \\
\hline Platelet & $<10 \mathrm{G} / \mathrm{L}$ & $150-400$ \\
\hline Schistocytes & $<1 \%$ & $<1 \%$ \\
\hline Neutrophils & $3.27 \mathrm{G} / \mathrm{L}$ & $1.8-7.5$ \\
\hline Eosinophils & $0.19 \mathrm{G} / \mathrm{L}$ & $0.02-0.8$ \\
\hline Lymphocytes & $1.65 \mathrm{G} / \mathrm{L}$ & $1-4$ \\
\hline Monocytes & $0.52 \mathrm{G} / \mathrm{L}$ & $0.2-0.9$ \\
\hline Haemostasis & Normal PT and aPTT & \\
\hline Fibrinogen & $2.23 \mathrm{~g} / \mathrm{L}$ & $2.13-4.22$ \\
\hline Factor V & $>150 \%$ & $61-142$ \\
\hline \multicolumn{3}{|l|}{ Blood chemistry } \\
\hline Creatinine & $86 \mu \mathrm{mol} / \mathrm{L}$ & 59-104 \\
\hline eGFR & $87.8 \mathrm{~mL} / \mathrm{min} / 1.73 \mathrm{~m}^{2}$ & $90.0-120.0$ \\
\hline AST & $202 \mathrm{IU} / \mathrm{L}$ & $15-37$ \\
\hline ALT & $483 \mathrm{IU} / \mathrm{L}$ & $16-61$ \\
\hline Alkaline phosphatase & $101 \mathrm{IU} / \mathrm{L}$ & 50-136 \\
\hline GGT & $292 \mathrm{IU} / \mathrm{L}$ & $15-85$ \\
\hline Total bilirubin & $13 \mu \mathrm{mol} / \mathrm{L}$ & $3-17$ \\
\hline Conjugated bilirubin & $4 \mu \mathrm{mol} / \mathrm{L}$ & $0-3$ \\
\hline Lacticodehydrogenase & $254 \mathrm{IU} / \mathrm{L}$ & $87-241$ \\
\hline Serum protein electrophoresis & Normal & \\
\hline Cryoglobulin & Negative & \\
\hline Myelogram & Normal cellularity & \\
\hline \multicolumn{3}{|l|}{ Serology } \\
\hline Syphilis & Negative & \\
\hline HIV & Negative & \\
\hline HBV & Positive for $\mathrm{Hbs} \mathrm{Ab}$ & \\
\hline CMV & Positive for lgG & \\
\hline EBV & Positive for lgG & \\
\hline \multicolumn{3}{|l|}{ Blood / plasma viral load } \\
\hline HCV RNA & $82,004 \mathrm{IU} / \mathrm{mL}$ & $<12$ \\
\hline CMV DNA & $0 \mathrm{IU} / \mathrm{mL}$ & $150-500$ \\
\hline EBV DNA & $348 \mathrm{IU} / \mathrm{mL}$ & $182-500$ \\
\hline HIV RNA & $<40$ copies $/ \mathrm{mL}$ & $<40$ \\
\hline Parvovirus B19 DNA & 0 copies $/ \mathrm{mL}$ & $70-87$ \\
\hline HHV6 DNA & 0 copies $/ \mathrm{mL}$ & \\
\hline HHV8 DNA & 0 copies $/ \mathrm{mL}$ & $500-2000$ \\
\hline
\end{tabular}

GGT Gamma Glutamine Transferase, PT Prothrombine time, aPTT Activated Partial Thromboplastin Time 


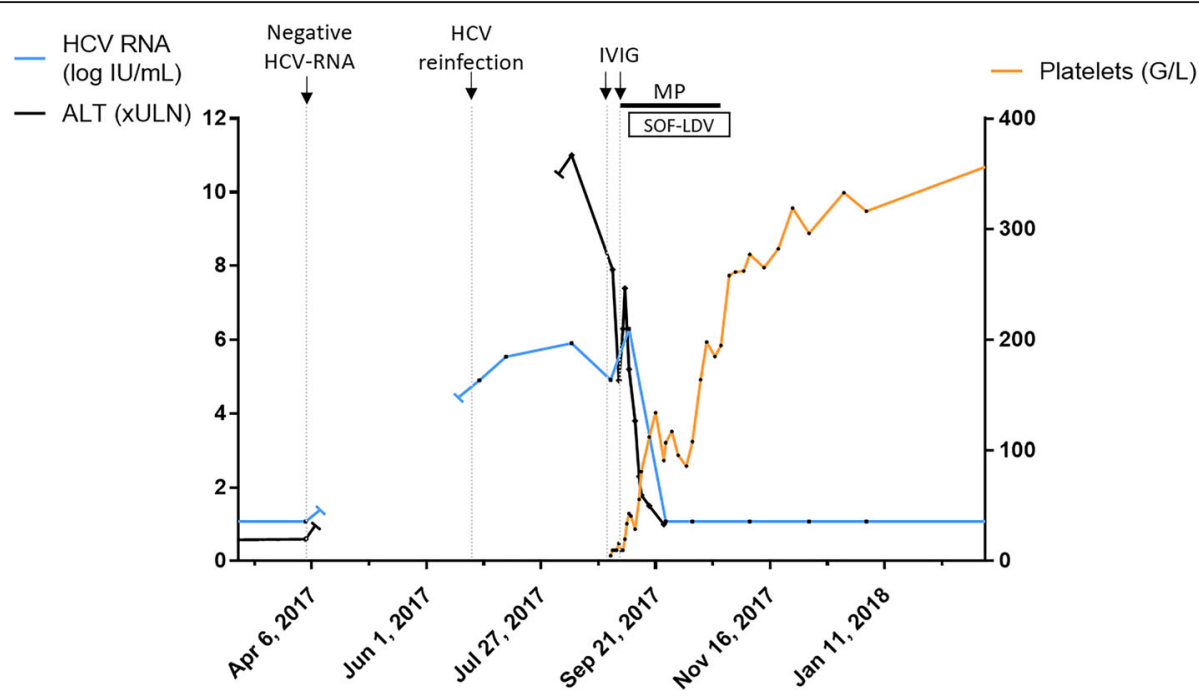

Fig. 1 Platelet and HCV viral load. Acute genotype 1a HCV reinfection was diagnosed on August 2017 on a systematic survey, with 11 XULN ALT and $5.91 \mathrm{log} \mathrm{IU} / \mathrm{mL}$ HCV RNA. Platelets were found at $5 \mathrm{G} / \mathrm{L}$ for the unit admission on August 30, 2017. First course of IVIG was administrated on August 31, at the dose of $1 \mathrm{~g} / \mathrm{kg}$ on day 1 and day 3, with clinical benefit but no effect on the platelet count. Second IVIG course was administrated on September 05 in association with methylprednisolone $1 \mathrm{mg} / \mathrm{kg}$ daily. Sofosbuvir-ledipasvir was started on September 11, allowing a sustained recovery of the platelet count with a quick viral load control (basal blue line represents an undetectable HCV viral load, inferior to $12 \mathrm{lU} / \mathrm{mL}$ ). IVIG: intravenous immunoglobulin, MP: methylprednisolone, SOF-LDV: sofusbuvir-ledispavir, ALT: Alanine transaminase, HCV: Hepatitis $C$ virus

therefore a 12 weeks course of sofosbuvir-ledipasvir was indicated. At initiation of the treatment, the platelet count was $43 \mathrm{G} / \mathrm{L}$ and $\mathrm{HCV}$ viral load was $6.3 \log \mathrm{IU} / \mathrm{mL}$. At day 15 of antiviral treatment, $\mathrm{HCV}$ viral load was undetectable $(<12 \mathrm{IU} / \mathrm{ml})$ and the platelet count had increased to $108 \mathrm{G} / \mathrm{L}$ allowing rapid tapering and discontinuation of corticosteroids before the end of antiviral therapy. HCV viral load remained undetectable until week 12 post-treatment, confirming HCV cure (Fig. 1). Platelet count fully normalised 5 weeks following treatment initiation and remained within normal range thereafter. The patient went through his 12 weeks course of sofosbuvir-ledipasvir with a good tolerance, without any specific adverse event reported.

\section{Discussion and conclusions}

Chronic HCV infection has been associated with immune thrombocytopenia; the incidence is estimated to be 30.253 cases / 100,000 person-years [5, 6]. Conversely, HCV antibodies have been found in 10 to $36 \%$ of patients with chronic ITP in cross-sectional studies [5, 6]. However, our case is a rare report of ITP in the context of acute hepatitis C. Only one similar case has already been reported by Narita et al. in 2003 [7]. According to this report, ITP also occurred at the second $\mathrm{HCV}$ infection after a first $\mathrm{HCV}$ infection cured by 6 months of IFN- $\alpha 2 b$. HCV genotype was found to be $2 a$ in this reinfection case, versus $2 b$ for the first one. In contrary to our findings, platelet associated immunoglobulins (PAIgG) were found positive in this report, with no other circulating antibodies (antinuclear antibody and rheumatoid factor were negative). Additionally, platelet count increased up to $39,000 / \mu \mathrm{L}$ spontaneously and the PAIgG returned to the normal ratio without any specific therapy while in our case, platelet count only recovered after specific antiviral therapy. Considering these differences, a distinct physiopathological mechanism may have been the source of ITP in these two cases.

Thrombocytopenia is frequent in viral infection. In such situations, a complex crosstalk between platelet and the virus is engaged and different mechanisms may contribute to two major events [8]: first, a decreased platelet production which can be induced by direct infection of megakaryocytes, infection of haematopoietic stem cells, induction of a type-1 IFN response leading to suppression of platelet formation, or modulation of liver thrombopoietin production; second, an increased platelet destruction, either by a direct contact during viraemia, interaction with immune complexes, cross-reactive antibodies directed against the virus, or proinflammatory events induced by the infection [8].

The exact mechanism of HCV-induced ITP is still not clear. Extra-hepatic manifestations are common in $\mathrm{HCV}$ infected patients, most of which are immune-related manifestations including mixed cryoglobulinaemia, arthralgia/ myalgia, and auto-antibody production [9]. Importantly, the presence of only anti-platelet antibodies is not associated 
with thrombocytopenia [10]. This leads to consider the potential role of immune complexes promoted by the presence of cross-reactive antibodies or a compensating mechanism following a decrease in thrombopoietin production [10]. A direct effect of the virus on megacaryocytes may also be suspected as HCV can bind to CD81 on the platelet membrane, and HCV-RNA has also been detected in washed platelets of infected patients [11]. Platelets could thus either favour the spread of the virus or contribute to its immune recognition by providing targetable antigens [10]. Moreover, detection of HCV-RNA with a higher frequency in platelets of thrombocytopenic patients suggest that $\mathrm{HCV}$ is directly involved in this process [12]. At this time, there is no evidence for a particular association between specific HCV genotypes and incidence of ITP [12].

The treatment of HCV-related ITP, particularly in the case of acute infection, is not standardized. Dufour et al. reported the outcome of 8 patients with HCV-related ITP [13]. Patients had a poor response to initial corticosteroids therapy, with only one complete response and three partial response. IVIG led to transient efficacy in three other patients. Of eight patients treated by antiviral therapy associating IFN- $\alpha$ with ribavirin, five responded. Normalisation of platelet count occurred in three responders, and normalisation of viral load was usually slow. Other authors have reported the increase of platelet count associated with complete $\mathrm{HCV}$ eradication after IFN therapy $[14,15]$. However, kinetic of platelet recovery was usually low in these cases.

Herein, we describe the case of a severe ITP associated with acute HCV reinfection. IVIG was chosen as the first-line therapy, owing to their efficacy in primary ITP and secondary ITP related to chronic HCV infection [6]. The absence of effect on the platelet count led to a second course of IVIG and administration of methylprednisolone, which improved only slightly the thombocytopenia. Sofosbuvir-ledipasvir treatment was then initiated which rapidly decreased viral load to under the limit of detection and normalised the platelet count. Interestingly, no drop back of platelet following corticosteroid discontinuation was observed. The acute installation of the thrombocytopenia, its refractoriness to the first-line immunomodulatory and immunosuppressive therapy, the rapid improvement following antiviral treatment and the absence of circulating anti-platelet antibodies suggest a predominant effect of direct viral-mediated platelet destruction in this context where the other adaptive mechanisms might not had the time to develop. Notably, the first HCV infection in the patient presented herein did not trigger any thrombocytopenia. There is currently no data on the risk on ITP following HCV reinfection and we can only speculate on the relation between the first infection and the ITP case.
In summary, we report herein the case of a secondary ITP associated with an acute genotype 1a HCV reinfection in a 54-year-old patient. Early treatment with sofosbuvir-ledispavir was followed by a rapid virological response and a sustained platelet count recovery, suggesting a viral-mediated platelet destruction corrected by the antiviral therapy.

\section{Additional file}

Additional file 1: Table S1. Laboratory data evolution. (XLSX $11 \mathrm{~kb}$ )

\section{Abbreviations}

HCV: Hepatitis C Virus; ITP: Immune thrombocytopenia; IVIG: Intravenous Immunoglobulin

\section{Acknowledgements}

Not applicable

Funding

This manuscript did not benefit from any funding.

Availability of data and materials

All data generated or analysed during this study are included in this published article and its Additional file 1.

Authors' contributions

VA, PM, CR, CC, and LC analysed and interpreted the patient data. VA wrote the final manuscript. PM and $L C$ reviewed and gave correction on the final version. All authors read and approved the final manuscript.

Ethics approval and consent to participate

Not applicable

Consent for publication

Written consent for publication was obtained from the patient.

\section{Competing interests}

The authors declare that they have no competing interests.

\section{Publisher's Note}

Springer Nature remains neutral with regard to jurisdictional claims in published maps and institutional affiliations.

\section{Author details}

${ }^{1}$ Département d'hématologie clinique, Hospices Civils de Lyon, Centre Hospitalier Lyon Sud, 69495 Pierre-Bénite, France. ${ }^{2}$ Inserm U1052, Centre de Recherche en Cancérologie de Lyon, 69008 Lyon, France. ${ }^{3}$ Service des maladies infectieuses et tropicales, Hospices Civils de Lyon, Hôpital de la Croix Rousse, 69004 Lyon, France. ${ }^{4}$ Laboratoire de virologie, Hospices civils de Lyon, Hôpital de la Croix Rousse, 69004 Lyon, France. ${ }^{5}$ INSERM U1111, Centre International de Recherche en Infectiologie, Lyon, France.

Received: 16 July 2018 Accepted: 7 December 2018

Published online: 19 December 2018

\section{References}

1. Lambert MP, Gernsheimer TB. Clinical updates in adult immune thrombocytopenia. Blood. 2017;129(21):2829-35.

2. Cines DB, Liebman $H$, Stasi R. Pathobiology of secondary immune thrombocytopenia. Semin Hematol. 2009;46(1 Suppl 2):S2-14.

3. Chiao EY, Engels EA, Kramer JR, Pietz K, Henderson L, Giordano TP, et al. Risk of immune thrombocytopenic purpura and autoimmune hemolytic anemia among 120908 US veterans with hepatitis C virus infection. Arch Intern Med. 2009;169(4):357-63. 
4. Ryom L, Boesecke C, Gisler V, Manzardo C, Rockstroh JK, Puoti M, et al. Essentials from the 2015 European AIDS clinical society (EACS) guidelines for the treatment of adult HIV-positive persons. HIV Med. 2016;17(2):83-8.

5. Pawlotsky JM, Bouvier M, Fromont P, Deforges L, Duval J, Dhumeaux D, et al. Hepatitis $C$ virus infection and autoimmune thrombocytopenic purpura. J Hepatol. 1995;23(6):635-9.

6. Dimitroulis D, Valsami S, Stamopoulos P, Kouraklis G. Immunological HCVAssociated Thrombocytopenia: Short Review. Clin Dev Immunol. 2012;2012 Available from: https://www.ncbi.nlm.nih.gov/pmc/articles/PMC3400398/. [cited 2018 Apr 24].

7. Narita R, Asaumi H, Abe S, Nakamura H, Tabaru A, Yoshikawa I, et al. Idiopathic thrombocytopenic purpura with acute hepatitis c viral infection. J Gastroenterol Hepatol. 2003;18(4):462-3.

8. Assinger A. Platelets and Infection - An Emerging Role of Platelets in Viral Infection. Front Immunol. 2014;5 Available from: https://www.frontiersin.org/ articles/10.3389/fimmu.2014.00649/full. [cited 2018 Jan 24].

9. Cacoub P, Comarmond C, Domont F, Savey L, Desbois AC, Saadoun D. Extrahepatic manifestations of chronic hepatitis $C$ virus infection. Ther Adv Infect Dis. 2016;3(1):3-14

10. Panzer S, Seel E, Brunner M, Körmöczi GF, Schmid M, Ferenci P, et al. Platelet autoantibodies are common in hepatitis $C$ infection, irrespective of the presence of thrombocytopenia. Eur J Haematol. 2006;77(6):513-7.

11. Hamaia S, Li C, Allain JP. The dynamics of hepatitis C virus binding to platelets and 2 mononuclear cell lines. Blood. 2001;98(8):2293-300.

12. de Almeida AJ, Campos-de-Magalhães M, de Melo Marçal OP, BrandãoMello CE, Okawa MY, de Oliveira RV, et al. Hepatitis C virus-associated thrombocytopenia: a controlled prospective, virological study. Ann Hematol. 2004;83(7):434-40

13. Dufour J-F, Pradat P, Ruivard M, Hot A, Dumontet C, Broussolle C, et al. Severe autoimmune cytopenias in treatment-naive hepatitis $C$ virus infection: clinical description of 16 cases. Eur J Gastroenterol Hepatol. 2009; 21(3):245.

14. Karasawa T, Togashi H, Tajima K, Suzuki A, Onodera S, Haga H, et al. Case of chronic type $\mathrm{C}$ hepatitis complicated with idiopathic thrombocytopenic purpura that was successfully treated by interferon therapy. Nihon Shokakibyo Gakkai Zasshi Jpn J Gastro-Enterol. 2009;106(3):405-10.

15. d'Alteroche L, Assor P. Lefrou L, Senecal D, Gaudy C, Bacq Y. Severe autoimmune neutropenia and thrombopenia associated with chronic $C$ hepatitis: effect of antiviral therapy. Gastroenterol Clin Biol. 2005;29(3):297-9.

Ready to submit your research? Choose BMC and benefit from:

- fast, convenient online submission

- thorough peer review by experienced researchers in your field

- rapid publication on acceptance

- support for research data, including large and complex data types

- gold Open Access which fosters wider collaboration and increased citations

- maximum visibility for your research: over $100 \mathrm{M}$ website views per year

At $\mathrm{BMC}$, research is always in progress.

Learn more biomedcentral.com/submissions 